\title{
ATPase Activity of the Subcellular Fractions of Colorectal Cancer Samples under the Action of Nicotinic Acid Adenine Dinucleotide Phosphate
}

\author{
Ivan Kushkevych ${ }^{1, *(\mathbb{D})}$, Mykola Bychkov ${ }^{2 * \mathbb{D}}$, Solomiia Bychkova ${ }^{3 * \mathbb{D}}$, Márió Gajdács ${ }^{4,5}$, Romana Merza ${ }^{6 *(\mathbb{D})}$ \\ and Monika Vítězová $1, * \mathbb{D}$
}

check for updates

Citation: Kushkevych, I.; Bychkov, M.; Bychkova, S.; Gajdács, M.; Merza, R.; Vítězová, M. ATPase Activity of the Subcellular Fractions of Colorectal Cancer Samples under the Action of Nicotinic Acid Adenine Dinucleotide Phosphate. Biomedicines 2021, 9, 1805. https://doi.org/10.3390/

biomedicines 9121805

Academic Editors: Antonio Biondi and Marco Vacante

Received: 21 October 2021

Accepted: 29 November 2021

Published: 30 November 2021

Publisher's Note: MDPI stays neutral with regard to jurisdictional claims in published maps and institutional affiliations.

Copyright: (c) 2021 by the authors. Licensee MDPI, Basel, Switzerland. This article is an open access article distributed under the terms and conditions of the Creative Commons Attribution (CC BY) license (https:/ / creativecommons.org/licenses/by/ $4.0 /)$.
1 Department of Experimental Biology, Faculty of Science, Masaryk University, 62500 Brno, Czech Republic

2 Department of Therapy No 1, Medical Diagnostic and Hematology and Transfusiology of Faculty of Postgraduate Education, Danylo Halytsky Lviv National Medical University, 79010 Lviv, Ukraine; therapy.fpdo@gmail.com

3 Department of Human and Animal Physiology, Faculty of Biology, Ivan Franko National University of Lviv, 79005 Lviv, Ukraine; solomiya.bychkova@lnu.edu.ua

4 Department of Oral Biology and Experimental Dental Research, Faculty of Dentistry, University of Szeged, 6720 Szeged, Hungary; gajdacs.mario@stoma.szote.u-szeged.hu

5 Faculty of Medicine, Institute of Medical Microbiology, Semmelweis University, Nagyvárad tér 4, 1089 Budapest, Hungary

6 Department of Anesthesiology and Intensive Care, Faculty of Postgraduate Education, Danylo Halytsky Lviv National Medical University, 79010 Lviv, Ukraine; merza_romana@meduniv.lviv.ua

* Correspondence: kushkevych@mail.muni.cz (I.K.); vitezova@sci.muni.cz (M.V.); Tel.: +420-549-495-315 (I.K.)

Abstract: In tumor cells with defects in apoptosis, autophagy allows prolonged survival. Autophagy leads to an accumulation of damaged mitochondria by autophagosomes. An acidic environment is maintained in compartments of cells, such as autophagosomes, late endosomes, and lysosomes; these organelles belong to the "acid store" of the cells. Nicotinic acid adenine dinucleotide phosphate (NAADP) may affect the release of $\mathrm{Ca}^{2+}$ from these organelles and affect the activity of $\mathrm{Ca}^{2+}$ ATPases and other ion transport proteins. Recently, a growing amount of evidence has shown that the variations in the expression of calcium channels or pumps are associated with the occurrence, diseasepresentation, and the prognosis of colorectal cancer. We hypothesized that activity of ATPases in cancer tissue is higher because of intensive energy metabolism of tumor cells. The aim of our study was to ascertain the effect of NAADP on ATPase activity on tissue samples of colorectal cancer patients' and healthy individuals. We tested the effect of NAADP on the activity of $\mathrm{Na}^{+} / \mathrm{K}^{+}$ ATPase; $\mathrm{Ca}^{2+}$ ATPase of endoplasmic reticulum (EPR) and plasma membrane (PM) and basal ATPase activity. Patients' colon mucus cancer samples were obtained during endoscopy from cancer and healthy areas (control) of colorectal mucosa of the same patients. Results. The mean activity of $\mathrm{Na}^{+} / \mathrm{K}^{+}$pump in samples of colorectal cancer patients $(n=5)$ was $4.66 \pm 1.20 \mu \mathrm{mol} \mathrm{P} \mathrm{P}_{\mathrm{i}} / \mathrm{mg}$ of protein per hour, while in control samples from healthy tissues of the same patient $(n=5)$ this value was $3.88 \pm 2.03 \mu \mathrm{mol} \mathrm{P}_{\mathrm{i}} / \mathrm{mg}$ of protein per hour. The activity of $\mathrm{Ca}^{2+}$ ATPase PM in control samples was $6.42 \pm 0.63 \mu \mathrm{mol} \mathrm{P} \mathrm{P}_{\mathrm{i}} / \mathrm{mg}$ of protein per hour and in cancer $-8.50 \pm 1.40 \mu \mathrm{mol} \mathrm{Pi} / \mathrm{mg}$ of protein per hour $(n=5 \mathrm{pts})$. The mean activity of $\mathrm{Ca}^{2+}$ ATPase of EPR in control samples was $7.59 \pm 1.21 \mu \mathrm{mol} \mathrm{P} / \mathrm{mg}$ versus $7.76 \pm 0.24 \mu \mathrm{mol} \mathrm{Pi} / \mathrm{mg}$ in cancer $(n=5 \mathrm{pts})$. Basal ATPase activity was $3.19 \pm 0.87$ in control samples versus $4.79 \pm 1.86 \mu \mathrm{mol} \mathrm{Pi} / \mathrm{mg}$ in cancer $(n=5 \mathrm{pts})$. In cancer samples, NAADP reduced the activity of $\mathrm{Na}^{+} / \mathrm{K}^{+}$ATPase by 9 -times $(p<0.01)$ and the activity of $\mathrm{Ca}^{2+}$ ATPase EPR about 2-times $(p<0.05)$. NAADP caused a tendency to decrease the activity of $\mathrm{Ca}^{2+}$ ATPase of PM, but increased basal ATPase activity by 2-fold vs. the mean of this index in cancer samples without the addition of NAADP. In control samples NAADP caused only a tendency to decrease the activities of $\mathrm{Na}^{+} / \mathrm{K}^{+}$ATPase and $\mathrm{Ca}^{2+}$ ATPase EPR, but statistically decreased the activity of $\mathrm{Ca}^{2+}$ ATPase of PM $(p<0.05)$. In addition, NAADP caused a strong increase in basal ATPase activity in control samples $(p<0.01)$. Conclusions: We found that the activity of $\mathrm{Na}^{+} / \mathrm{K}^{+}$ pump, $\mathrm{Ca}^{2+}$ ATPase of PM and basal ATPase activity in cancer tissues had a strong tendency to be higher than in the controls. NAADP caused a decrease in the activities of $\mathrm{Na}^{+} / \mathrm{K}^{+}$ATPase 
and $\mathrm{Ca}^{2+}$ ATPase EPR in cancer samples and increased basal ATPase activity. In control samples, NAADP decreased $\mathrm{Ca}^{2+}$ ATPase of PM and increased basal ATPase activity. These data confirmed different roles of NAADP-sensitive "acidic store" (autophagosomes, late endosomes, and lysosomes) in control and cancer tissue, which hypothetically may be connected with autophagy role in cancer development. The effect of NAADP on decreasing the activity of $\mathrm{Na}^{+} / \mathrm{K}^{+}$pump in cancer samples was the most pronounced, both numerically and statistically. Our data shows promising possibilities for the modulation of ion-transport through the membrane of cancer cells by influence on the "acidic store" (autophagosomes, late endosomes and lysosomes) as a new approach to the treatment of colorectal cancer.

Keywords: cancer; NAADP; $\mathrm{Ca}^{2+}$; autophagy; acidic store; ATPase; $\mathrm{Ca}^{2+}$ ATPase; EPR; $\mathrm{Ca}^{2+}$ ATPase $\mathrm{PM} ; \mathrm{Na}^{+} / \mathrm{K}^{+}$ATPase; basal ATPase activity

\section{Introduction}

Malignant diseases constitute the second leading cause of death worldwide, and their importance is continuously increasing with the onset of the epidemiological transition and the ageing of the population globally. Colorectal cancer (CRC) is the third most commonly diagnosed type of cancer in the world and is the fourth leading cause of death from malignancy [1]. A critical role in the development of bowel cancer may be attributed to microbial communities residing in them, which produce hydrogen sulfide $\left(\mathrm{H}_{2} \mathrm{~S}\right)$ [2-5], affecting not only the microbiota-composition of the individual, but also the health and physiology of the surrounding bowel cells [6-9].

Disruption of autophagy processes plays an important role in tumor formation [10]. Normally, autophagy is a continuous reparative process of maintaining cellular homeostasis, involving organelles, such as lysosomes and autophagosomes. These organelles belong to the so-called "acid storage" of the cells [11]. Nicotinic acid adenine dinucleotide phosphate (NAADP) may affect the release of $\mathrm{Ca}^{2+}$ from these organelles [12]. Apoptotic pathways are suppressed in tumor cells, and the process of autophagy further prolongs the life of atypical cells. Conversely, disorders of autophagy in normal cells may lead to their transformation into malignant cells, due to the accumulation of defective proteins. Therefore, it is important to ascertain the features and the functioning of the acid storage in both healthy individuals and patients affected by cancer, as well as the role of NAADP in their biological functions [13]. The differential diagnosis of CRC is important, as other illnesses—such as gastro-intestinal infections [14], irritable bowel syndrome, Chron's disease, or hemorrhoids-may have a similar disease-presentation initially [15].

There is insufficient knowledge on the mechanism of action of NAADP in cancer cells, in particular, the role of NAADP in the $\mathrm{Ca}^{2+}$ homeostasis of cancer cells. There is a large transmembrane electrochemical gradient of $\mathrm{Ca}^{2+}$ between the cytosol and the intracellular environment, which leads to the entry of the $\mathrm{Ca}^{2+}$ ion into the cell; For the appropriate maintenance of cell signaling, it is very important to maintain a consistent, low concentration of this cation, which is achieved by the activity of $\mathrm{Ca}^{2+}$ pumps. Changes in plasma membrane calcium ATPase (PMCA) expression have been observed in various types of malignancies [16]. A close association was found between mutations in the $\mathrm{Ca}^{2+}$ ATPase EPR gene and a sharp increase in the incidence of tumors in mice [17]. The $\mathrm{Na}^{+} / \mathrm{K}^{+}$ ATPase may also be an interesting target for antitumor therapy [18].

As a part of this study, we aimed to determine the effect of NAADP on the activity of $\mathrm{Ca}^{2+}$ pumps in control and cancer samples. In addition, our investigation also aimed to answer whether the activity of the $\mathrm{Na}^{+} / \mathrm{K}^{+}$pump differs in control (healthy) and colorectal cancer samples, and to evaluate the effect of NAADP on this ATPase.

Thus, the aim of our study was to determine the effect of NAADP on the energy metabolism with regard to the activity of ATPases of human colorectal cancer cells, in comparison to samples of healthy tissue of patients' colon mucosa. 
To achieve this goal, we set the following tasks:

- To estimate the effect of NAADP on the activity of $\mathrm{Na}^{+} / \mathrm{K}^{+}$ATPase;

- To ascertain the effect of NAADP on the activities of $\mathrm{Ca}^{2+}$ ATPase of endoplasmic reticulum (EPR) and the plasma membrane (PM);

- To research the effect of NAADP on the basal ATPase activity in the patients' colorectal cancer samples compared to the samples of healthy tissues.

The results of our study may clarify the role of the NAADP-sensitive "acid storage" (lysosomes, late endosomes, and autophagosomes) and systems of active ion transport (ATPases) in healthy and cancer cells, in addition to aiding the identification of novel targets in anti-cancer treatment.

\section{Materials and Methods}

\subsection{Ethical Standards and Characteristics of Patients}

The study was conducted according to the guidelines of the Declaration of Helsinki, and approved by the Institutional Review Board (Ethics Committee) of Department of Therapy No 1, Medical diagnostic and Hematology and Transfusiology of Faculty of Postgraduate Education, Danylo Halytsky Lviv National Medical University (protocol code No. 5, 2 September 2021).

A total of 15 patients with colorectal cancer (mean age is $58.6 \pm 1.4$ years) were complex examined, only 5 patients agreed to provide colorectal samples during endoscopy. The diagnosis of colorectal cancer was established according to the unified clinical protocol No 703 from 7 December 2016 on the basis of histological conclusion on the basis of morphological examination of the biopsy. Patients' colon mucus cancer samples were obtained during endoscopy from areas affected by cancer and healthy areas (control) of colorectal mucosa of the same patients. From one patient we obtained two samples: cancer tissue and healthy tissue (control). All patients signed an informed-consent document for diagnosis and research on tissue specimens before being enrolled in the project.

\subsection{Isolation of Subcellular Post-Mitochondrial Fraction of the Patients' Colon Mucus}

Tissue samples were collected from patients' colons during colonoscopy. Fresh samples were washed by medium A: sucrose $(250 \mathrm{mM})$, ethylene glycol tetra-acetic acid (EGTA) $(1 \mathrm{mM})$, HEPES $(10 \mathrm{mM}) ; \mathrm{KH}_{2} \mathrm{PO}_{4}(1 \mathrm{mM}) ; \mathrm{pH}$ 7.2. Then, these samples were homogenized with glass-glass homogenizer at $300 \mathrm{rev} / \mathrm{min}$ for $10 \mathrm{~min}$ at $0-2{ }^{\circ} \mathrm{C}$. The homogenate was centrifuged for $10 \mathrm{~min}$ at $3000 \mathrm{~g}$ using a Jouan MR 1812 centrifuge (Jouan, France) to precipitate nuclei, large cells fragments, and undestroyed cells, while mitochondria remained in the supernatant 1 . Next, centrifugation of this supernatant 1 was carried out for $10 \mathrm{~min}$ at $8500 \mathrm{~g}\left(0-2{ }^{\circ} \mathrm{C}\right)$. After sedimentation of the mitochondria, supernatant 2 was used for ATPase activity assay. To verify the membrane's presence in the post-mitochondrial fraction it was centrifuged for $20 \mathrm{~min}$ at $15,000 \mathrm{~g}$.

\subsection{Assay of ATPase Activity}

ATPase activity of these patients' samples of colon mucus was estimated in postmitochondrial subcellular fraction which was obtained by separate centrifugations as it was described previously for NK/Ly cells [18]. Briefly, tissue samples homogenized with a glass-glass homogenizer at $300 \mathrm{rpm}$ for $10 \mathrm{~min}$ at $0{ }^{\circ} \mathrm{C}$ to $2{ }^{\circ} \mathrm{C}$. The homogenate was centrifuged for $10 \mathrm{~min}$ at $3000 \mathrm{~g}$ using JouanMR 1812 centrifuge (Jouan, France) to precipitate nuclei, large cells fragments, and undestroyed cells, whereas mitochondria remained in the supernatant 1 . Then, the mitochondrial fraction was sedimented by further centrifugation of this supernatant for $10 \mathrm{~min}$ at $8500 \mathrm{~g}\left(0-2{ }^{\circ} \mathrm{C}\right)$. After mitochondria sedimentation, supernatant 2 was sedimented for $20 \mathrm{~min}$ at $14,000 \mathrm{~g}$ and was used for ATPase activity assay. Consequently, the obtained post-mitochondrial fraction was analyzed using electronic microscopy to prove the presence of membrane vesicles, such as autophagosomes, microsomes, lysosomes, and endosomes. 
ATPase activity was measured spectrophotometrically by the Fiske-Subbarow method estimating the level of inorganic phosphorus $\left(\mathrm{P}_{\mathrm{i}}\right)$, which is released during the ATP hydrolase reaction, and was expressed in $\mu \mathrm{mol} \mathrm{Pi} / \mathrm{mg}$ of protein per hour.

Briefly this post-mitochondrial subcellular fraction was transferred to a standard internal solution containing (mM) NaCI, 50.0; $\mathrm{KCl}, 100.0 ;$ Tris- $\mathrm{HCl}, 20.0 ; \mathrm{MgCl}_{2}, 3.0 ; \mathrm{CaCl}_{2}$, 0.01 ; $\mathrm{pH} 7.0$ at $37^{\circ} \mathrm{C}$. The reaction was started by adding $3 \mathrm{mM}$ ATP (Sigma, Burlington, MA, USA). NAADP (Sigma, USA) in concentrations $1 \mu \mathrm{M}$ was added to incubation suspension for estimating its effect on ATPase activity.

- The activity of $\mathrm{Na}^{+} / \mathrm{K}^{+}$ATPase was expressed as the difference of $\mathrm{P}_{\mathrm{i}}$ in the medium with or without ouabain (Sigma, USA). The samples (without ouabain) instead contained incubation medium in equal measure. Basal $\mathrm{Mg}^{2+}$ ATPase activity was determined in an incubation medium that did not contain $\mathrm{CaCl}_{2}$, but included EGTA, as well as ouabain. Thapsigargin (Sigma, USA) was added to inhibit the activity of the $\mathrm{Ca}^{2+}$ ATP of EPR. The activity of $\mathrm{Ca}^{2+}$ ATP of EPR was also calculated as the difference of $P_{i}$ in the medium with inhibitors (thapsigargin and ouabain) or without these compounds. The samples (without thapsigargin and ouabain) contained incubation medium in equal measure;

- Thapsigargin and ouabain were previously dissolved in DMSO in a separate aliquot, then dissolved again in another aliquot in internal solution and then was added to the incubation medium in concentration $1 \mu \mathrm{mol}$. Other samples (without thapsigargin and ouabain) instead contained incubation medium in equal measure.

NAADP $(1 \mu \mathrm{M})$ (Sigma, USA) was added to the incubation medium to determine its effect on ATPase activity. ATPase activity was expressed as micromoles of inorganic phosphorus, equivalent to $1 \mathrm{mg}$ of protein per $1 \mathrm{~h}$ ( $\mu \mathrm{mol} \mathrm{P}_{\mathrm{i}} / \mathrm{mg}$ of protein per hour).

\subsection{Calculation of Specific ATPase Activity}

The total ATPase activity of the post-mitochondrial fraction of colon mucous was calculated by the difference of inorganic phosphorus in the media with different compositions: (a) specific $\mathrm{Na}^{+} / \mathrm{K}^{+}$ATPase activity was calculated as difference of inorganic phosphorus content in medium with or without ouabain $(1 \mathrm{mM}) ;(b)$ for the determination of $\mathrm{Ca}^{2+} / \mathrm{Mg}^{2+}$ ATPase activity, the difference between the total $\mathrm{Ca}^{2+} / \mathrm{Mg}^{2+}$ and $\mathrm{Na}^{+} / \mathrm{K}^{+}$-ATPase activity was quantified (c) thapsigargin was used to calculate SERCA (sarco/endoplasmic reticulum $\mathrm{Ca}^{2+}$ ATPase) contribution into the total $\mathrm{Ca}^{2+} / \mathrm{Mg}^{2+} \mathrm{ATPase}^{2}$ activity (d) specific basal $\mathrm{Mg}^{2+}$ ATPase activity was determined in an incubation medium that contained $1 \mathrm{mM}$ EGTA and lacked ouabain. In all experiments, the incubation medium was used as a control for the enzymatic ATP hydrolysis.

\subsection{Statistical Analysis}

We calculated such statistical indexes as $M$ is mean and $m$ is standard error of the mean. The data in text are expressed as mean \pm SEM. We used the Kolmogorov-Smirnov test (K-S test) for verifying compliance with parametric (normal) distribution. The significance of differences between experimental groups was calculated using Wilcoxon-Mann-Whitney, when the data distributions were not normal, while Student's $t$-test was used when data distribution was normal. Statistical processing of information was performed using the Software SPSS Statistics 17.0 (SPSS, Inc., Chicago, IL, USA) $p<0.05$ was considered to be statistically significant.

\section{Results}

3.1. Evaluation of the Effect of NAADP on the Activity of $\mathrm{Na}^{+} / \mathrm{K}^{+}$ATPase of Post-Mitochondrial Fraction of Human Colorectal Cancer Tissue Samples vs. Normal Tissue

The mean activity of $\mathrm{Na}^{+} / \mathrm{K}^{+}$ATPase of post-mitochondrial fraction in colorectal cancer patients' (pts) samples was $4.66 \pm 1.20 \mu \mathrm{mol} \mathrm{P}_{\mathrm{i}} / \mathrm{mg}$ of protein per hour $(n=5 \mathrm{pts})$. In control samples (from healthy colorectal mucosa tissues) of the same patient $(n=$ 5 pts) this value was $3.88 \pm 2.03 \mu \mathrm{mol} \mathrm{P}_{\mathrm{i}} / \mathrm{mg}$ of protein per hour. Thus the activity of 
$\mathrm{Na}^{+} / \mathrm{K}^{+}$ATPase was approximately $20 \%$ higher in cancer samples compared to their control counterparts (Figure 1A), but this increase was not statistically significant.

$\boldsymbol{A}$
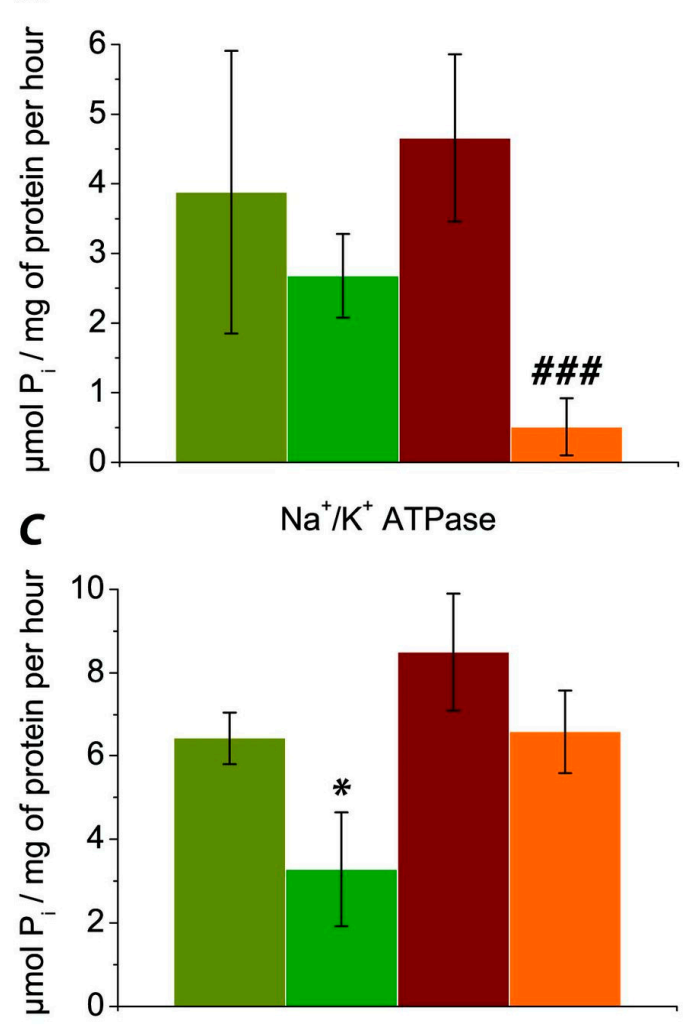

$\mathrm{Ca}^{2+}$ ATPase activity of PM

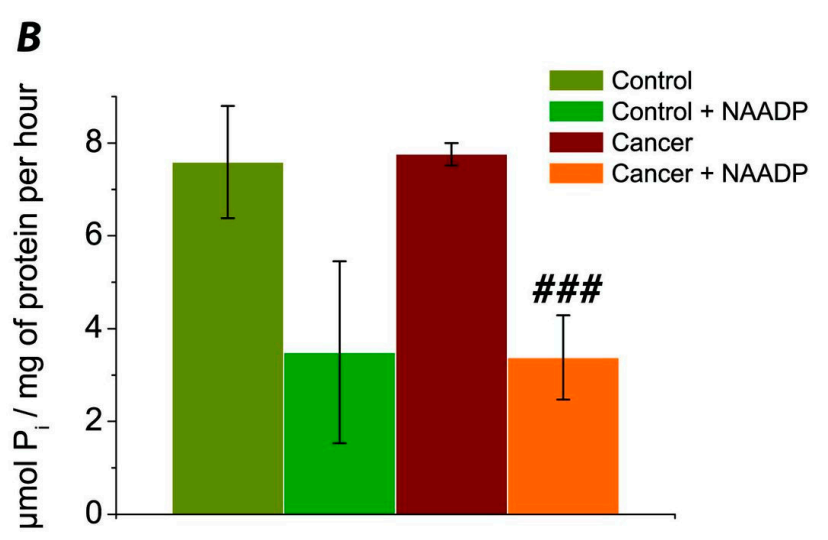

D $\quad \mathrm{Ca}^{2+}$ ATPase of EPR

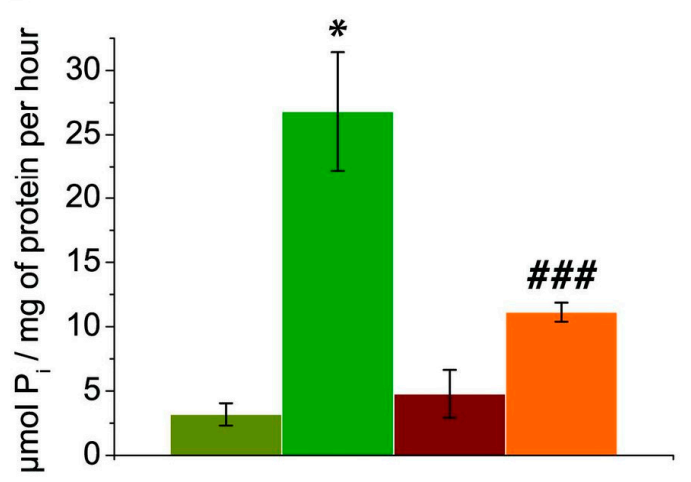

Basal ATPase activity

Figure 1. Comparison of NAADP effect on ATPase activity ( $\mu \mathrm{mol} \mathrm{P}_{\mathrm{i}} / \mathrm{mg}$ of protein per hour) in colorectal mucosa samples from healthy area of patients' mucosa (control) and the samples of colorectal tumor's area of the same patients (cancer): $\mathrm{Na}^{+} / \mathrm{K}^{+}$ATPase activities, $n=5$ pts. ( 5 samples of control vs. 5 cancer samples) (A); Ca ${ }^{2+}$ ATPase of EPR, $n=5$ pts. (5 samples of control vs. 5 cancer samples) (B); $\mathrm{Ca}^{2+}$ ATPase activity of PM, $n=5$ pts. (4 samples of control vs. 5 cancer samples) (C); Basal ATPase activity, $n=5$ pts. (5 samples of control vs. 5 cancer samples) (D). ${ }^{*}$ indicates $p<0.05$ (vs. control); \#\#\# is $p<0.01$ (vs. cancer). The data are expressed as mean \pm standard error of the mean.

When NAADP was added to the control medium of incubation of these samples, the mean activity of $\mathrm{Na}^{+} / \mathrm{K}^{+}$ATPase was $2.68 \pm 0.60 \mu \mathrm{mol} \mathrm{P} / \mathrm{mg}$ of protein per hour ( $n=5$ pts). Thus, NAADP reduced the activity of $\mathrm{Na}^{+} / \mathrm{K}^{+}$ATPase in control, but this effect was not statistically significant $(p>0.05)$. In cancer samples, adding NAADP extremally decreased the mean activity of $\mathrm{Na}^{+} / \mathrm{K}^{+}$ATPase to $0.51 \pm 0.41 \mu \mathrm{mol} \mathrm{P}_{\mathrm{i}} / \mathrm{mg}$ of protein per hour (Figure 1A). Therefore, NAADP statistically decreased the activity of $\mathrm{Na}^{+} / \mathrm{K}^{+}$ATPase by 9 -times in cancer samples $(p<0.01)$. Hence, the effect of NAADP on inhibition of the activity of $\mathrm{Na}^{+} / \mathrm{K}^{+}$pump was more effective in cancer tissue.

\subsection{Determination of the Effect of NAADP on the Activity of $\mathrm{Ca}^{2+}$ ATPase EPR of the Post-Mitochondrial Fraction of Colorectal Cancer Tissue Samples vs. Normal Tissue}

In control patients' tissue samples, the activity of $\mathrm{Ca}^{2+}$ ATPase EPR of the postmitochondrial fraction of colon mucosa showed a mean of $7.59 \pm 1.21 \mu \mathrm{mol} \mathrm{P}_{\mathrm{i}} / \mathrm{mg}$ of protein per hour ( $n=5 \mathrm{pts}$ ). In cancer samples, the activity of $\mathrm{Ca}^{2+}$ ATPase EPR varied from 7.00 to 8.26 , with a mean value of $7.76 \pm 0.24 \mu \mathrm{mol} \mathrm{P}_{\mathrm{i}} / \mathrm{mg}$ of protein per hour ( $n=5$ pts), which is only slightly higher than in samples from control tissues (Figure 1B). When NAADP was added to the control, the activity of $\mathrm{Ca}^{2+}$ ATPase EPR amounted to $3.49 \pm 1.96 \mu \mathrm{mol} \mathrm{P}$ i $/ \mathrm{mg}$ of protein per hour ( $n=5 \mathrm{pts})$. Thus, NAADP showed the 
tendency to decrease the activity of $\mathrm{Ca}^{2+}$ ATPase EPR in control. Under the influence of NAADP on the subcellular fraction of cancer samples, the mean activity of $\mathrm{Ca}^{2+}$ ATPase EPR was $3.38 \pm 0.91 \mu \mathrm{mol} \mathrm{P}_{\mathrm{i}} / \mathrm{mg}$ of protein per hour $(n=5 \mathrm{pts})$. This decreasing was statistically significant $(p<0.01)$.

Thus, NAADP reduced the activity of $\mathrm{Ca}^{2+}$ ATPase EPR in both control and cancer cells by about 2-times (Figure 1B), but this effect was statistically significant only in cancer samples.

\subsection{The Effect of NAADP on the Activity of $\mathrm{Ca}^{2+}$ ATPase PM of the Post-Mitochondrial Fraction of Colorectal Cancer Cells vs. Normal Tissue}

Activity of $\mathrm{Ca}^{2+}$ ATPase of PM in control samples was $6.42 \pm 0.63 \mu \mathrm{mol} \mathrm{P}_{\mathrm{i}} / \mathrm{mg}$ of protein per hour ( $n=4$ pts). Unfortunately we have only 4 control samples, because one was lost during the experiments. In samples of colorectal cancer tissue, the activity of $\mathrm{Ca}^{2+}$ ATPase of PM was $8.50 \pm 1.40 \mu \mathrm{mol} \mathrm{P} / \mathrm{mg}$ of protein per hour $(n=5 \mathrm{pts})$. Thus the activity of $\mathrm{Ca}^{2+}$ ATPase of PM had a tendency to be higher in cancer samples comparatively to control tissue (Figure 1C). Incubation the of post-mitochondrial fraction of control samples with NAADP caused a statistically significant $(p<0.05)$ decrease in the activity of $\mathrm{Ca}^{2+}$ ATPase of PM by approximately 2 fold to $3.28 \pm 1.36 \mathrm{~mol} \mathrm{P}$ i $/ \mathrm{mg}$ of protein per hour ( $n=4$ pts). Adding NAADP to the post-mitochondrial fraction of colorectal cancer samples decreased the activity of this pump to $6.58 \pm 1.00 \mu \mathrm{mol} \mathrm{P}_{\mathrm{i}} / \mathrm{mg}$ of protein per hour ( $n=5$ pts), but this effect was not statistically significant.

Thus, NAADP statistically decreased the activity of $\mathrm{Ca}^{2+}$ ATPase of PM in control samples (Figure 1C) and showed the tendency to decrease this index in cancer samples as well.

\subsection{Comparison of Basal ATPase Activity without Exposure and under the Action of NAADP}

In control samples of patients' colorectal mucosa (Figure 1D), the basal ATPase activity ranged from 0.42 to 5.88 , the mean was $3.19 \pm 0.87 \mu \mathrm{mol} \mathrm{P}_{\mathrm{i}} / \mathrm{mg}$ of protein per hour ( $n=5$ pts). Basal ATPase activity of colorectal cancer samples ranged from 2.10 to 9.66, with a mean of $4.79 \pm 1.86 \mu \mathrm{mol} \mathrm{P}_{\mathrm{i}} / \mathrm{mg}$ of protein per hour ( $\left.n=5 \mathrm{pts}\right)$. So, a tendency to increase the basal ATPase activity in cancer vs. control was observed. After NAADPtreatment of control samples, basal ATPase activity increased significantly and showed $26.80 \pm 4.62 \mu \mathrm{mol} \mathrm{P} \mathrm{i}_{\mathrm{i}} / \mathrm{mg}$ of protein per hour ( $\left.n=5 \mathrm{pts}\right)$. Thus, NAADP caused 8-fold, statistically significant increases of this index $(p<0.01)$ vs. control. When NAADP was added to the incubation medium of cancer samples, the mean of basal ATPase activity was $11.13 \pm 0.74 \mu \mathrm{mol} \mathrm{P}_{\mathrm{i}} / \mathrm{mg}$ of protein per hour $(n=5 \mathrm{pts})$, which was 2 -fold higher vs. mean of this index in cancer samples without NAADP treatment.

Thus, NAADP caused a strong increase in basal ATPase activity by 8-folds in control samples and only a 2-fold increase in this index in the control.

\section{Discussion}

We hypothesized that the activity of ATPase in cancer tissue is higher than in healthy tissue, due to the intensive energy metabolism of tumor cells, which is a prerequisite for their continuous cell division and proliferation [19]. Our results confirmed this assumption: the activity of $\mathrm{Na}^{+} / \mathrm{K}^{+}$pump and $\mathrm{Ca}^{2+}$ ATPase of PM in cancer tissues was higher than in healthy ones by $17 \%$ and $24 \%$, respectively, but this increase was not statistically significant $(p>0.05)$. Activity of $\mathrm{Ca}^{2+}$ ATPase of EPR and basal ATPase activity did not have very significant changes in cancer tissue, in comparison to control samples. This may be explained by the fact that $\mathrm{Ca}^{2+}$ ATPase of EPR is often inhibited in cancer, because SERCA inhibition is thought to promote cell survival [20].

The $\mathrm{Na}^{+} / \mathrm{K}^{+}$pump is a transmembrane protein complex that maintains the ionic and osmotic balance of the cells of higher eukaryotes. This ATPase is a universal transducer and integrator of cellular signals, and it plays a key role in cell adhesion [12]. Abnormal expression of this protein is associated with the development and progression of various 
types of malignancies. It has been shown that the expression of $\alpha$ - and $\beta$-subunits of $\mathrm{Na}^{+} / \mathrm{K}^{+}$ATPase of cancer and normal cells differs considerably, thus creating a powerful diagnostic tool and target for the action of inhibitors and ligands of the sodium-potassium pump [17].

We found that the activity of this pump in cancer tissues was about $20 \%$ higher than in control samples, but this increase was not statistically significant. However, observed tendency to increasing the activity of $\mathrm{Na}^{+} / \mathrm{K}^{+}$ATPase in cancer is in agreement with findings of other authors, showing that the baseline expression and activity of $\mathrm{Na}^{+} / \mathrm{K}^{+}$ ATPase were enhanced in breast cancer, compared to a non-tumorigenic breast cell line [21], in patients with ovarian serous cystadenocarcinoma [22]. In samples of patients' colorectal cancer, highly expressed $\mathrm{Na}^{+} / \mathrm{K}^{+}$ATPase isozymes were found [23]. We established a statistically significant decrease in $\mathrm{Na}^{+} / \mathrm{K}^{+}$ATPase activity under the action of NAADP in cancer samples and strong tendency to reduced this pump in control: NAADP reduced the activity of $\mathrm{Na}^{+} / \mathrm{K}^{+}$ATPase in colorectal cancer samples by 9.1 times. This result is similar to our previous findings regarding the effects of NAADP, studied on murine NK/Ly cells [19], as well as in a model system consisting of rat liver tissue [24].

This effect of NAADP may be explained by a powerful release of $\mathrm{Ca}^{2+}$ from the acidic stores by NAADP, causing an inhibitory effect on $\mathrm{Na}^{+} / \mathrm{K}^{+}$ATPase activity. For example, such an inhibitory effect of higher intracellular $\mathrm{Ca}^{2+}$ on the sodium pump was shown for human red blood cells [25]. Another possible explanation may be related to the $\mathrm{pH}$ change caused by the effects of NAADP. A.J. Morgan et al. estimated that NAADP caused alkalization of the endo-lysosomal lumen [26]. Thus, it is also likely that NAADP decreased activity of $\mathrm{Na}^{+} / \mathrm{K}^{+}$ATPase due to change in $\mathrm{pH}$. Alkalization of the biological environment to higher than $\mathrm{pH} 7.5$ inhibits this protein, as well as the process of acidification to $\mathrm{pH}$ values lower than 6.0 [27].

In our case, NAADP indirectly caused an inhibitory effect on $\mathrm{Na}^{+} / \mathrm{K}^{+}$ATPase activity. It also was shown that inhibitors of $\mathrm{Na}^{+} / \mathrm{K}^{+}$ATPase exhibit antitumor effects on hepatocellular carcinoma models [28]. The study of Trenti and co-authors [29] showed that inhibition of $\mathrm{Na}^{+} / \mathrm{K}^{+}$ATPase promotes autophagy and causes an anticancer effect. The hypothetical role of autophagy in this process was confirmed by our experiments which use NAADP as a tool to target acidic stores (autophagosomes, late endosomes, and lysosomes) and indirectly inhibit $\mathrm{Na}^{+} / \mathrm{K}^{+}$ATPase. Thus, this ATPase may present as a potent target in anticancer treatment.

$\mathrm{Ca}^{2+}$ ATPases are a key factor in maintaining the asymmetric distribution of calcium ions between different cell compartments. Remodeling of $\mathrm{Ca}^{2+}$ signaling is an important step in cancer progression. The expression of $\mathrm{Ca}^{2+}$ pumps is highly regulated in breast cancer cells [30]. Increased gene expression of this protein has been found in various types of cancers [15]. Changes in PMCA-expression and related changes in the release of calcium from the cell in colon cancer cells contribute to cancer growth [31].

We found that NAADP caused a tendency to decrease the activity of $\mathrm{Ca}^{2+}$ ATPase of PM in patients' colorectal cancer tissue, but in control samples, this effect was more pronounced. NAADP caused statistically significant reduction in the activity of $\mathrm{Ca}^{2+}$ ATPase of PM by 2 folds. Some studies suggest that PMCA4 affects the colon cancer cell growth cycle and cell death. PMCA4 is overly expressed in higher differentiated human colon cancer samples and HT-29, Caco-2 cells. This suggests that PMCA4 affects colorectal cancer cell death [32]. PMCA4-knockout cells are able to avoid the decrease in cellular viability, and cause a lack of sensitivity to apoptotic stimuli [33].

$\mathrm{Ca}^{2+}$ ATPases of EPR pump $\mathrm{Ca}^{2+}$ into the endoplasmic reticulum lumen modulating cytosolic $\mathrm{Ca}^{2+}$ concentrations to regulate various cellular processes including cell growth. A downregulation of SERCA3 protein expression was reported in gastric and colon cancer cell lines and showed that in vitro cell differentiation increases its expression [30]. Here, it was estimated that NAADP showed the tendency to decrease the activity of $\mathrm{Ca}^{2+}$ ATPase EPR in control but it statistically reduced the activity of $\mathrm{Ca}^{2+}$ ATPase of EPR in cancer samples 
$(p<0.01)$. We suppose that NAADP decreased $\mathrm{Ca}^{2+}$ ATPase activity due to releasing $\mathrm{Ca}^{2+}$ from the "acid storage".

Our data are consistent with previous findings observed on murine NK/Ly cells: NAADP decreased activities of $\mathrm{Ca}^{2+}$ ATPase of EPR and basal $\mathrm{Mg}^{2+}$ ATPase [19]. Recently Pawan Faris et al. have shown that NAADP induces intracellular $\mathrm{Ca}^{2+}$ release through the two-pore channel TPC1 in metastatic colorectal cancer cells [34].

We observed different effects of NAADP on $\mathrm{Ca}^{2+}$ ATPase EPR and PM in control and colorectal cancer patients' samples. These data confirmed distinctive roles of NAADPsensitive "acidic store" (autophagosomes, late endosomes, and lysosomes) in control (healthy) and cancer tissue, which hypothetically may be associated with the role of autophagy in cancer development.

We also observed an extremely large increase in (8.4 fold) the activity of basal $\mathrm{Mg}^{2+}$ ATPase by NAADP in control colon tissue samples. This agrees with our previous findings on rat's liver tissue [24]. This effect is not associated with the increasing $\mathrm{Ca}^{2+}$ concentration because of the presence of EGTA in the incubation medium. We explain such effects with changes of pH. S. O. Kosterin et al. [27] showed that $\mathrm{H}^{+}$is a competitive inhibitor of a given enzyme: the increase in proton concentration leads to a decrease in the affinity of $\mathrm{Mg}^{2+}$ ATP substrate. Thus NAADP not only releases $\mathrm{Ca}^{2+}$ from acidic stores, but simultaneously changes $\mathrm{pH}$ in subcellular fraction of human colorectal cancer, probably due to a $\mathrm{Ca}^{2+}$ $\mathrm{H}^{+}$-exchanger in membranes of these organelles. In cancer tissue, this effect of NAADP on activity of basal $\mathrm{Mg}^{2+}$ ATPase was not as pronounced (only a 2 fold increase). This probably indicates a different role for NAADP-sensitive acidic storages in cancer cells.

Thus, the obtained data show promising possibilities for the modulation of iontransport through the membrane of cancer cells by influence on "acidic store" (autophagosomes, late endosomes, and lysosomes) as a potentially new approach to the treatment of colorectal cancer. These results expand the understanding of the mechanisms of cancer development and the role of NAADP-sensitive acid stores in this process and also highlight possible therapeutic targets for cancer treatment.

\section{Conclusions}

During our study, we have found that the activity of $\mathrm{Na}^{+} / \mathrm{K}^{+}$pump and $\mathrm{Ca}^{2+}$ ATPase of PM in cancer tissues had a tendency to be higher than in control. Activity of the calcium ATPase of EPR and basal ATPase activity were not very intensively changed in cancer tissue comparison to control. NAADP causes a decrease in the activities of $\mathrm{Na}^{+} / \mathrm{K}^{+}$ATPase, $\mathrm{Ca}^{2+}$ ATPase EPR, and $\mathrm{Ca}^{2+}$ ATPase of PM in both control and cancer samples, except basal ATPase activity, which was increased by NAADP. The effect of NAADP on decreasing the activity of $\mathrm{Na}^{+} / \mathrm{K}^{+}$pump in cancer samples was especially pronounced. Thus, based on our experimental results, NAADP modulates ATPase activity in cancer tissues and can decrease the energetic status of tumor cells. This makes NAADP a potential tool in the future of cancer treatment.

Author Contributions: Conceptualization, M.B. and S.B.; methodology, M.B. and S.B.; software, I.K.; validation, I.K., M.B., S.B. and M.V.; formal analysis, I.K. and M.G.; investigation, M.B. and S.B.; resources, M.B.; data curation, M.B. and S.B.; writing-original draft preparation, S.B., I.K., M.G., M.B. and R.M.; writing-review and editing, I.K., S.B., M.G. and R.M.; visualization, I.K., S.B. and R.M.; supervision, M.B. and M.V.; project administration, I.K.; funding acquisition, I.K. and M.G. All authors have read and agreed to the published version of the manuscript.

Funding: This research was supported by the Grant Agency of Masaryk University (MUNI/A/1425/2020). M.G. was supported by the János Bolyai Research Scholarship (BO/00144/20/5) of the Hungarian Academy of Sciences. The research was supported by the UNKP-21-5-540-SZTE New National Excellence Program of the Ministry for Innovation and Technology from the source of the National Research, Development and Innovation Fund. M.G. would also like to acknowledge the support of ESCMID's “30 under 30" Award. 
Institutional Review Board Statement: The study was conducted according to the guidelines of the Declaration of Helsinki, and approved by the Institutional Review Board (Ethics Committee) of Department of Therapy No 1, Medical diagnostic and Hematology and Transfusiology of Faculty of Postgraduate Education, Danylo Halytsky Lviv National Medical University (protocol code No. 5, 2 September 2021).

Informed Consent Statement: Written informed consent has been obtained from the patient(s) to publish this paper.

Data Availability Statement: Not applicable.

Conflicts of Interest: The authors declare no conflict of interest.

\section{References}

1. Rawla, P.; Sunkara, T.; Barsouk, A. Epidemiology of Colorectal Cancer: Incidence, Mortality, Survival, and Risk Factors. Prz. Gastroenterol 2019, 14, 89-103. [CrossRef] [PubMed]

2. Cummings, J.H.; Macfarlane, G.T.; Macfarlane, S. Intestinal Bacteria and Ulcerative Colitis. Curr. Issues Intest. Microbiol. 2003, 4, 9-20. [PubMed]

3. Kushkevych, I.; Cejnar, J.; Treml, J.; Dordević, D.; Kollar, P.; Vítězová, M. Recent Advances in Metabolic Pathways of Sulfate Reduction in Intestinal Bacteria. Cells 2020, 9, 698. [CrossRef] [PubMed]

4. Kushkevych, I.; Leščanová, O.; Dordević, D.; Jančíková, S.; Hošek, J.; Vítězová, M.; Buňková, L.; Drago, L. The Sulfate-Reducing Microbial Communities and Meta-Analysis of Their Occurrence during Diseases of Small-Large Intestine Axis. JCM 2019, 8, 1656. [CrossRef]

5. Gibson, G.R.; Cummings, J.H.; Macfarlane, G.T. Growth and Activities of Sulphate-Reducing Bacteria in Gut Contents of Healthy Subjects and Patients with Ulcerative Colitis. FEMS Microbiol. Lett. 1991, 86, 103-112. [CrossRef]

6. Kushkevych, I.; Dordević, D.; Kollár, P. Analysis of Physiological Parameters of Desulfovibrio Strains from Individuals with Colitis. Open Life Sci. 2019, 13, 481-488. [CrossRef]

7. Dordević, D.; Jančíková, S.; Vítězová, M.; Kushkevych, I. Hydrogen Sulfide Toxicity in the Gut Environment: Meta-Analysis of Sulfate-Reducing and Lactic Acid Bacteria in Inflammatory Processes. J. Adv. Res. 2020, 27, 55-69. [CrossRef]

8. Kushkevych, I.; Kotrsová, V.; Dordević, D.; Buňková, L.; Vítězová, M.; Amedei, A. Hydrogen Sulfide Effects on the Survival of Lactobacilli with Emphasis on the Development of Inflammatory Bowel Diseases. Biomolecules 2019, 9, 752. [CrossRef]

9. Kushkevych, I.; Dordević, D.; Vítězová, M. Possible Synergy Effect of Hydrogen Sulfide and Acetate Produced by SulfateReducing Bacteria on Inflammatory Bowel Disease Development. J. Adv. Res. 2020, 27, 71-78. [CrossRef]

10. Yun, C.; Lee, S. The Roles of Autophagy in Cancer. Int. J. Mol. Sci. 2018, 19, 3466. [CrossRef]

11. Yim, W.W.-Y.; Mizushima, N. Lysosome Biology in Autophagy. Cell Discov. 2020, 6, 6. [CrossRef]

12. Alevizopoulos, K.; Calogeropoulou, T.; Lang, F.; Stournaras, C. Na $\mathrm{Na}^{+}$ATPase Inhibitors in Cancer. Curr. Drug Targets 2014, 15, 988-1000. [CrossRef]

13. Lee, H.C. Nicotinic Acid Adenine Dinucleotide Phosphate (NAADP)-Mediated Calcium Signaling. J. Biol. Chem. 2005, 280, 33693-33696. [CrossRef]

14. Axelrad, J.E.; Lichtiger, S.; Yajnik, V. Inflammatory Bowel Disease and Cancer: The Role of Inflammation, Immunosuppression, and Cancer Treatment. World J. Gastroentero. 2016, 22, 4794. [CrossRef] [PubMed]

15. Curry, M.C.; Roberts-Thomson, S.J.; Monteith, G.R. Plasma Membrane Calcium ATPases and Cancer. BioFactors 2011, 37, 132-138. [CrossRef]

16. Prasad, V.; Okunade, G.W.; Miller, M.L.; Shull, G.E. Phenotypes of SERCA and PMCA Knockout Mice. Biochem. Biophys. Res. Commun. 2004, 322, 1192-1203. [CrossRef] [PubMed]

17. Mijatovic, T.; Dufrasne, F.; Kiss, R. Na $/ \mathrm{K}^{+}$-ATPase and Cancer. Pharm. Pat. Anal. 2012, 1, 91-106. [CrossRef]

18. Ferents, I.M.; Bychkova, S.V.; Bychkov, M.A. Peculiarities of the Effects of Bile Acids on Atpase Activity of the Colon Mucosa in Patients with Overweight and Irritable Bowel Syndrome. Wiad. Lek. 2020, 73, 574-577. [CrossRef] [PubMed]

19. Hreniukh, V.; Bychkova, S.; Kulachkovsky, O.; Babsky, A. Effect of Bafilomycin and NAADP on Membrane-Associated ATPases and Respiration of Isolated Mitochondria of the Murine Nemeth-Kellner Lymphoma: Mitochondria and ATPase Activities in Lymphoma. Cell Biochem. Funct. 2016, 34, 579-587. [CrossRef] [PubMed]

20. Chemaly, E.R.; Troncone, L.; Lebeche, D. SERCA Control of Cell Death and Survival. Cell Calcium 2018, 69, 46-61. [CrossRef] [PubMed]

21. Khajah, M.A.; Mathew, P.M.; Luqmani, Y.A. $\mathrm{Na}^{+} / \mathrm{K}^{+}$ATPase Activity Promotes Invasion of Endocrine Resistant Breast Cancer Cells. PLOS ONE 2018, 13, e0193779. [CrossRef]

22. Huang, W.; Zhang, Y.; Xu, Y.; Yang, S.; Li, B.; Huang, L.; Lou, G. Comprehensive Analysis of the Expression of Sodium/PotassiumATPase $\alpha$ Subunits and Prognosis of Ovarian Serous Cystadenocarcinoma. Cancer Cell Int. 2020, 20, 309. [CrossRef]

23. Baker Bechmann, M.; Rotoli, D.; Morales, M.; del Maeso, M.C.; del García, M.P.; Ávila, J.; Mobasheri, A.; Martín-Vasallo, P. $\mathrm{Na}$,K-ATPase Isozymes in Colorectal Cancer and Liver Metastases. Front. Physiol. 2016, 7, 9. [CrossRef] [PubMed] 
24. Bychkova, S. Influence of NAADP and Bafilomycine A1 on Activity of ATPase in Liver Postmitochondrial Fraction. Biol. Stud. 2015, 9, 31-40. [CrossRef]

25. Brown, A.M.; Lew, V.L. The Effect of Intracellular Calcium on the Sodium Pump of Human Red Cells. J. Physiol. 1983, 343, 455-493. [CrossRef]

26. Morgan, A.J.; Davis, L.C.; Wagner, S.K.T.Y.; Lewis, A.M.; Parrington, J.; Churchill, G.C.; Galione, A. Bidirectional Ca ${ }^{2+}$ Signaling Occurs between the Endoplasmic Reticulum and Acidic Organelles. J. Cell Biol. 2013, 200, 789-805. [CrossRef] [PubMed]

27. Kosterin, S.O.; Veklich, T.O.; Pryluts'kyi, I. Kinetic interpretation of the original pH-dependence of enzymatic activity of "basal” $\mathrm{Mg}^{2+}$ ATPase of the smooth muscle sarcolemma. Ukr. Biokhim. Zh. 2005, 2005, 37-45.

28. Song, Y.; Lee, S.-Y.; Kim, S.; Choi, I.; Kim, S.-H.; Shum, D.; Heo, J.; Kim, A.-R.; Kim, K.M.; Seo, H.R. Inhibitors of Na ${ }^{+} \mathrm{K}^{+}$ATPase $^{-}$ Exhibit Antitumor Effects on Multicellular Tumor Spheroids of Hepatocellular Carcinoma. Sci. Rep. 2020, 10, 5318. [CrossRef] [PubMed]

29. Trenti, A.; Grumati, P.; Cusinato, F.; Orso, G.; Bonaldo, P.; Trevisi, L. Cardiac Glycoside Ouabain Induces Autophagic Cell Death in Non-Small Cell Lung Cancer Cells via a JNK-Dependent Decrease of Bcl-2. Biochem. Pharmacol. 2014, 89, 197-209. [CrossRef]

30. Varga, K.; Hollósi, A.; Pászty, K.; Hegedûs, L.; Szakács, G.; Tímár, J.; Papp, B.; Enyedi, Á.; Padányi, R. Expression of Calcium Pumps Is Differentially Regulated by Histone Deacetylase Inhibitors and Estrogen Receptor Alpha in Breast Cancer Cells. BMC Cancer 2018, 18, 1029. [CrossRef]

31. Prevarskaya, N.; Skryma, R.; Shuba, Y. Targeting Ca ${ }^{2+}$ Transport in Cancer: Close Reality or Long Perspective? Expert Opin. Ther. Targets 2013, 17, 225-241. [CrossRef] [PubMed]

32. Ribiczey, P.; Tordai, A.; Andrikovics, H.; Filoteo, A.G.; Penniston, J.T.; Enouf, J.; Enyedi, Á.; Papp, B.; Kovács, T. Isoform-Specific up-Regulation of Plasma Membrane $\mathrm{Ca}^{2+}$ ATPase Expression during Colon and Gastric Cancer Cell Differentiation. Cell Calcium 2007, 42, 590-605. [CrossRef] [PubMed]

33. Aung, C.S.; Ye, W.; Plowman, G.; Peters, A.A.; Monteith, G.R.; Roberts-Thomson, S.J. Plasma Membrane Calcium ATPase 4 and the Remodeling of Calcium Homeostasis in Human Colon Cancer Cells. Carcinogenesis 2009, 30, 1962-1969. [CrossRef] [PubMed]

34. Faris, P.; Pellavio, G.; Ferulli, F.; Di Nezza, F.; Shekha, M.; Lim, D.; Maestri, M.; Guerra, G.; Ambrosone, L.; Pedrazzoli, P.; et al. Nicotinic Acid Adenine Dinucleotide Phosphate (NAADP) Induces Intracellular $\mathrm{Ca}^{2+}$ Release through the Two-Pore Channel TPC1 in Metastatic Colorectal Cancer Cells. Cancers 2019, 11, 542. [CrossRef] [PubMed] 